\title{
The Practice of Indigenous Education for Students with Disabilities in the Selected Church Schools of South Gondar Administrative Towns-Ethiopia
}

Getachew Walelign Asres ( $\sim$ getawalelign@yahoo.com )

Debre Tabor University https://orcid.org/0000-0003-4311-3286

\section{Research Article}

Keywords: Indigenous, Indigenous Education, Disabilities, Students with Disabilities, Church

Posted Date: December 15th, 2021

DOI: https://doi.org/10.21203/rs.3.rs-1118140/v1

License: (c) (i) This work is licensed under a Creative Commons Attribution 4.0 International License.

Read Full License 


\section{Abstract}

The main objective of this study is to assess the practice of indigenous education for students with disabilities in Ethiopian indigenous schools. Therefore, 20 Orthodox Church schools were purposefully selected in order to make them representatives of South Gondar Administrative towns. The result of the study showed that there was no ability difference between students with disabilities and students without disabilities in the different levels of the church schools $(X 2=0.62$ and its Chi-square per item is 1.509, $.521, .036,1.393, .158, .015, .793, .100$, and 1.050 at $\mathrm{df}=1, \mathrm{p}=.220, .471, .850, .238, .691, .902, .373, .751$ and $.305>0.05$ from items 1-9 respectively). In addition, church scholars could not use special assessment techniques for students with disabilities in the different church schools. Inaccessible environment is the major challenge that impede the educational performance of students with disabilities. Therefore, students with disabilities need different support services from stakeholders.

\section{Introduction}

In indigenous education, it is believed that people with disabilities are not considered as unable to perform educational activities and not comes as a result of their or parents sins. For instance Bible described as 'at one time, God teaches his disciples that a lame person was cured. At that time, people asked Jesus Christ, why was he born handicapped? Was it because of his sins, his mother's sins, or his family's sins that he became handicapped? Jesus Christ answered it was not because of his sins or his family's sins; it was because God wanted to show a miracle to the world.

Indigenous African learning plays a vital role in the transmission of value that Africans considered to be essential in understanding and experiencing the fullness of life. Because, it is interwove in the fabric of African life, indigenous education is inseparable from traditional African religious thought and practices there is no dichotomy between religious and secular thought and values (Mbiti, 1990 as cited in Tedla, 1992). Thus, Africans do not speak of education as a process or institution separate from everything else in life. There is no distinction between formal, non-formal, or informal education. In fact, the term education is a Western concept that does not speak to the traditional African reality, in which the entire community is continually engaged in learning and teaching.

Before the dawn of $20^{\text {th }} \mathrm{C}$, the Ethiopian school system had been dominated by religious teachings. The educational schooling of the Ethiopian Orthodox Church and the Mosque were the dominant traditional educations (Teshome, 1979). However, it is undeniable that it was the Ethiopian Orthodox Church school system that used to have the upper hand. Religious organizations played a vital role in establishing special schools and centers on Ethiopia as they did in the development of special schools \& individuals are among the ones that established training centers, and special schools as well as in training and teaching people with special needs (Bairu , 1967; Adane , 1991 as cited in Zelalem , 2014). In addition, indigenous Ethiopian church education takes 30 to 34 years of arduous and exacting studies - 30 years for the serious and hard working students. According to Kalewold (1970) as cited in Tedla (1992), "occasionally one may even come across highly gifted individuals that take only 25 or even 24 years to 
do the whole job". For instance, a dedicated student begins school at the age of 5 and completes his education by age 35 . In the same vein, in traditional Africa, learning begins very early in life soon after birth and continues to old age. In supporting this, Menkiti (1984) describes it, the whole of life is a process of learning to become fully human to attain personhood.

Ethiopian church education is divided into the following major schools or centers of learning: (a) nebab bet, (b) zema bet, (c) kine bet and (d) metsahift bet. Nebab Bet (House of Reading) generally takes 2 years (Sertse, 2006). These learning centers consist of reading, writing, and learning by heart. The Ethiopian fidel or script is used, and various prayers to Mary and Jesus, including the Psalms of David, are learned by heart. (B). Zema Bet (house of religious music) includes the following branches: (1) the study of Tsome-Degua, the Meiraf and the Degua (fundamental books of religious music composed by Yared, founder of Ethiopian Church music), which usually takes four years, (2) the study of Kedase (Mass music) and the Saatat (special religious music to be recited only at night time) for six months, (3) the study of more refined, and complex kinds of religious music, Zemare and Mewaseit, for one year, and (4) a three year study of A qua quam, the department of religious music which deals with the religious dance, in which drums and sistra are used. (Kalewold, 1970 as cited in Tedla, 1992). Kedase (liturgy) has been wrongly translated as "Mass music" in the above quotation. The Ethiopian church have its own musical notes (invented by Qidous Yared, an Ethiopian saint). (C). Kine Bet (House of poetry) takes about 5 years. Here poetry and Ge'ez language and grammar are taught. (Ge'ez is the language of the Ethiopian Tewhado Church). (D). Metsahift Bet (House of Books) is the final stage of higher learning and consists of several branches of study. It takes 4 years to study the scriptures (biblical knowledge); 3 years to study the Likawnt (church fathers) and Metsehafe-Menekosat, "which defines the rules and spiritual disciplines governing the life of the monks"; 6 months to learn Merha Ewur, which deals with computation of church calendars; 1 year to study church history and 4 years to learn arts and crafts (Atlabachew , 2002).

As church chroniclers narrate the situation, in Ethiopia, people with disabilities have been participating in the indigenous education earlier than modern education though few in numbers. There were students around churches and mosques who were visually and physically impaired. These students were successful even though the education was given orally. This was confirmed by the presence of visually and physically impaired teachers around mosques and monasteries who teach Koran, Bible, Poem, and rhythmical religious songs even today. Like their fellow friends, persons with disabilities were expected to pass through all levels of church education, which requires a long time. However, persons with hearing and intellectually impaired weren't part of church education because of the nature of schooling. Predominantly, the teaching methodology of church education was oral. Historically, those who succeeded in their education were able to get positions and power (Adane, 1991 as cited in Zelalem , 2014). In the history of Ethiopian church education, hence, people with disabilities had a convincing role in taking part of scholastic voyage.

Thus, assessing the actual educational practice for students with disabilities in indigenous educational programs is worthwhile for realizing quality education that the church and government is giving top most priority today for the education of students with disabilities in Ethiopia. Despite a number of researches 
were carried out in relation to the educational condition of students with disabilities in the modern education program, scant attention is given on the status and condition of the indigenous education on people with disabilities in Ethiopian Orthodox church. Therefore, studying the actual practices of indigenous educational programs for students with disabilities in the church is crucial to the Church, students with and without disabilities, and government in order to design a better educational approach, and scaling up students' knowledge, and skills in secular and religious issues. This initiated the researchers to conduct research on the practice of indigenous education for students with disabilities in the church schools in South Gondar Zone, Amhara region.

To this end; the researchers formulated the following leading questions:

1. Do the educational abilities and performance of students with disabilities in the different levels of church schools the same as that of students without disabilities?

2. Do the methods of teaching that church scholars employed in the different levels of church education are appropriate for students with disabilities?

3. How church scholars assess the educational performance of students with disabilities in the different levels of church schools?

4. What support services has been provided for students with disabilities in the church schools by peers and their teachers in order to scale up their academic performance?

\section{Methods And Materials}

\subsection{Design of the Study}

Non- experimental design was used for this research. Particularly, a mixed research approach was employed for this research. It comprises both quantitative and qualitative data for a better understanding the educational practice of students with disabilities in Ethiopian church schools.

\subsection{Churches Covered by the Study}

Every church and monastery in Ethiopia has at least one church school. Moreover, every village has its church, and nearly every church has its school. In this study, 20 orthodox church schools were purposefully selected in order to make them representatives of South Gondar Administrative towns in particular and south Gondar administrative Zone in general ( 6 from Debre Tabor, 2 from Mekaneyesus, 5 from Gayint, and 6 from Woreta and 1 from Addis Zemen).

\subsection{Participants}

The participants of this study were students with disabilities (selected through convenient sampling technique), church scholars (purposive sampling technique) and students without disabilities (simple random sampling technique) of the sample church schools. Thus, a total of 43 students with disabilities; 
163 students without disabilities and 14 church scholars (teachers) were the participants of the study. By using Yamane (1967) simplified formula, the sample size selected from the above population was 236. However, 30(12.7\%) questionnaires were not returned. All these participants were males. This is because female students have not been participated in the history of church education.

\subsubsection{Inclusion Criteria}

This study included those students with and without disabilities that have been attending their education in the selected Orthodox Church. In addition, the study included only students with visible and/or severe disability (sensory and physical disabilities) and those students that were easily accessible to the researchers.

\subsection{Data Gathering Instruments}

The data gathering instruments used for this study to gather information in relation to the practice of indigenous / church education for students with disabilities were a questionnaire, interview, and Focus Group Discussion (FGD). A questionnaire was the main data gathering instrument where as FGD and interview were used as a supplementary data gathering instruments and used for triangulation purpose. Self-developed questionnaire was used to gather data onto different respondents. Pilot test was conducted to check the reliability and validity of the instrument. This study found a Cronbach alpha of 0.79 for the full item.

\subsection{Data Analysis Method}

Both quantitative and qualitative data analyses techniques were employed. That is, descriptive and inferential statistics were used as quantitative methods of data analysis that are obtained from questionnaire. I.e. inferential statistics like Chi-square (X2-square) analysis was employed for the quantitative data. Whereas, descriptive statistics using, frequency count and percentages were used to calculate participants' background information, educational performance, teaching \& assessment methods used, support services provided and challenges impede the educational performance of students with disabilities. The qualitative data were also used to analyze the data by creating themes from the academic performance, service provisions and methods of teaching and evaluation techniques employed.

\subsection{Ethical Consideration}

All research involving human beings should be conducted in accordance with three basic ethical principles, namely respect for persons, beneficence and justice. Hence, students with \& without disabilities, and church scholars were told about the purpose of the study and their consent. No one was involved in this study against his/her will. Oral consent was obtained before the questionnaire was given to the respondents and the interview was held with the interviewee. Participants were also assured that their response remained strictly confidential, and personal details were kept anonymous. Respondents 
were notified that they have the right to refuse or terminate at any point of the participation. Finally, the researcher used pseudonyms instead of their real names when the data was analyzed.

\section{Result}

\subsection{Demographic Information}

Many of the respondents (55.82\%) was fall in the age range of $16-20$ years old followed by $19.9 \%$ age range of $10-16$ years, $16.5 \%$ age range of $21-25$ years, $7.77 \%$ age range of $26-30$ years. In addition, majority of the respondents, 107 (51.94\%) were attended their education at Zema bet followed by 95(46. $12 \%)$ Kene bet, $3(1.46 \%)$, Nibab Bet and other $1(0.49 \%)$ is found to be Mesthafit bet. Furthermore, 98(47.57\%) respondents found to be at Debre Tabor, 37(17.96\%) were drown from Woreta, 34(16.5\%) were from Mekaneyesus, followed by 23(11.16\%) from Gayint and 14(6.8\%) were from Addis Zemen. Besides, majority of the respondents $154(74.76 \%)$ was stayed from year $1-5$. Others $41(19.98 \%), 8(3$. $88 \%), 3(1.46 \%)$ were staying $6-10,11-15$, and $16-20$ years respectively in the church schools. Finally, $163(71.13 \%)$ were non-disabled whereas $43(28.87 \%)$ respondents were students with disabilities. These inferred that respondents were drawn from different age groups, educational level, and administrative towns.

The distribution of the study groups by disability condition falls between $21.42 \%$ and $42.86 \%$. That is, $5(35.71 \%)$ were blind, $3(21.42 \%)$ physical disabled and the remaining $6(42.86 \%)$ were non- disabled students. Being disabled help the church scholars to provide valid and reliable data onto the educational condition of students with disabilities in the church schools. The figure also showed that most interviewed church scholars have more than 5 years of teaching experiences. This long experience helps the respondent to provide real, genuine and sufficient information onto church schools. In addition, these respondents were selected from the five administrative towns and church schools. The respondents were also selected from different levels of the church school.

Many of the respondents $8(53.3 \%)$ was blind, and the remaining $7(46.7 \%)$ was physical disabled. Other types of disabled students were not included in the study. This entails that many students, especially students with visual and physical impaired have been participating in the different levels of the church schools (66.67\%, 26.67\% and 6.67\% Zema, Kene and Metshift bet respectively).

\subsection{Educational Conditions in Indigenous Education}

\section{3 .2.1 Educational Abilities}

Table 1: Educational Abilities of Students with Disabilities in the Church Education 


\begin{tabular}{|c|c|c|c|c|c|}
\hline & \multirow[t]{2}{*}{ Items } & \multicolumn{2}{|c|}{ Agree } & \multicolumn{2}{|c|}{ Disagree } \\
\hline & & $f$ & $\%$ & $f$ & $\%$ \\
\hline 1 & $\begin{array}{l}\text { The educational abilities of students with disabilities in all } \\
\text { levels of the church education is the same as that of students } \\
\text { without disabilities. }\end{array}$ & 145 & 70.39 & 61 & 29.61 \\
\hline 2 & $\begin{array}{l}\text { Students with disabilities have better academic abilities in } \\
\text { lower levels of church education than the higher levels (house } \\
\text { of pottery and house of books). }\end{array}$ & 58 & 28.16 & 148 & 71.84 \\
\hline 3 & $\begin{array}{l}\text { Students with disabilities have scored lower in all academic } \\
\text { areas due to inconvenient teaching-learning methodology. }\end{array}$ & 41 & 19.9 & 165 & 80.1 \\
\hline 4 & $\begin{array}{l}\text { The educational ability of students with disabilities are different } \\
\text { based on their disability type. }\end{array}$ & 198 & 96.11 & 8 & 3.89 \\
\hline 5 & $\begin{array}{l}\text { The Educational ability of students with disabilities are better in } \\
\text { theoretical related areas than those program that required } \\
\text { practical performance( house of pottery and books) }\end{array}$ & 158 & 76.7 & 48 & 23.3 \\
\hline 6 & $\begin{array}{l}\text { Students with disabilities have better abilities in both theoretical } \\
\text { and practical subject areas }\end{array}$ & 37 & 18 & 169 & 82 \\
\hline 7 & $\begin{array}{l}\text { Disability/ Impairment does not have an impact on the } \\
\text { educational abilities of students' with disabilities }\end{array}$ & 150 & 72.8 & 56 & 27.2 \\
\hline 8 & $\begin{array}{l}\text { Students with disabilities have completed their education latter } \\
\text { in all levels of the church education than when compared to } \\
\text { students without disabilities. }\end{array}$ & 171 & 83 & 35 & 17 \\
\hline 9 & $\begin{array}{l}\text { Students with disabilities have completed all levels of the } \\
\text { church education as the same time as students without } \\
\text { disabilities because of having low abilities }\end{array}$ & 50 & 24.27 & 156 & 75.73 \\
\hline
\end{tabular}

As showed in table 1, majority of the respondents 145(70.39)\%) replied that the educational ability of students with disabilities is the same as that of their non-disabled peers and few of them $(29.61 \%)$ stated that these groups of students did not have the same abilities in all levels of the church education. Conversely, many of the respondents, $148(71.84 \%)$ disagreed with the issue that students with disabilities have lower abilities in the higher levels of the church education and vice versa. In addition to this, most of the respondents (80.1\%) also disagreed with the statement 'lower score of students come as a result of inconvenient teaching -learning methodology'. Furthermore, most respondents $158(76.7 \%)$ agreed that students with disabilities have better abilities on those theoretical related educational programs than on those programs that require practical performances (like the way of standing' or 'moving' especially in aqwaqwam for monthly and annual festivals accompanied by sistra, prayer sticks and drums executed by the choir when singing).

With regard to the impact of disability on the educational ability of students with disabilities, majority of respondents $150(72.8 \%)$ reported that disability does not have an impact on their educational abilities and performances. Similarly, $171(83 \%)$ of respondents pointed out that students with different disability 
groups were not finished their education with the same period as that of students without disability in the different levels of the church education due to lack of support provided.

\section{Chi-square $\left(X^{2}\right)$ Score}

\begin{tabular}{|c|c|c|c|c|c|c|}
\hline I & Items & $H C$ & $A$ & $D S$ & $X^{2}$ Value & Sig. \\
\hline \multirow[t]{2}{*}{1} & \multirow{2}{*}{$\begin{array}{l}\text { Educational abilities of students with } \\
\text { disabilities in all levels of the church education } \\
\text { is the same as that of students without } \\
\text { disabilities }\end{array}$} & Disability & 27 & 16 & \multirow[t]{2}{*}{1.509} & \multirow[t]{2}{*}{.220} \\
\hline & & $\begin{array}{l}\text { N. } \\
\text { Disability }\end{array}$ & 119 & 44 & & \\
\hline \multirow[t]{2}{*}{2} & \multirow{2}{*}{$\begin{array}{l}\text { Students with disabilities have better academic } \\
\text { abilities in lower levels of church education than } \\
\text { the higher levels( house of pottery and house of } \\
\text { books) }\end{array}$} & Disability & 14 & 29 & \multirow[t]{2}{*}{.521} & \multirow[t]{2}{*}{.471} \\
\hline & & $\begin{array}{l}\text { N. } \\
\text { Disability }\end{array}$ & 44 & 119 & & \\
\hline \multirow[t]{2}{*}{3} & \multirow{2}{*}{$\begin{array}{l}\text { Students with disabilities have scored lower in } \\
\text { all academic areas due to inconvenient } \\
\text { teaching-learning methodology. }\end{array}$} & Disability & 9 & 34 & \multirow[t]{2}{*}{.036} & \multirow[t]{2}{*}{.850} \\
\hline & & $\begin{array}{l}\text { N. } \\
\text { Disability }\end{array}$ & 32 & 131 & & \\
\hline \multirow[t]{2}{*}{44} & \multirow{2}{*}{$\begin{array}{l}\text { The educational ability of students with } \\
\text { disabilities are different based on their disability } \\
\text { type. }\end{array}$} & Disability & 40 & 3 & \multirow[t]{2}{*}{1.393} & \multirow[t]{2}{*}{.238} \\
\hline & & $\begin{array}{l}\text { N. } \\
\text { Disability }\end{array}$ & 160 & 3 & & \\
\hline \multirow[t]{2}{*}{5} & \multirow{2}{*}{$\begin{array}{l}\text { The Educational ability of students with } \\
\text { disabilities are better in theoretical subject areas } \\
\text { than on those subjects that required practical } \\
\text { performance }\end{array}$} & Disability & 32 & 11 & \multirow[t]{2}{*}{.158} & \multirow[t]{2}{*}{.691} \\
\hline & & $\begin{array}{l}N . \\
\text { Disability }\end{array}$ & 126 & 37 & & \\
\hline \multirow[t]{2}{*}{6} & \multirow{2}{*}{$\begin{array}{l}\text { Students with disabilities have better abilities in } \\
\text { both theoretical and practical subject areas }\end{array}$} & Disability & 8 & 35 & \multirow[b]{2}{*}{.015} & \multirow[b]{2}{*}{.902} \\
\hline & & $\begin{array}{l}\text { N. } \\
\text { Disability }\end{array}$ & 27 & 136 & & \\
\hline \multirow[t]{2}{*}{7} & \multirow{2}{*}{$\begin{array}{l}\text { Disability/Impairment does not have an impact } \\
\text { on students' with disabilities educational } \\
\text { abilities }\end{array}$} & Disability & 29 & 14 & \multirow[t]{2}{*}{.793} & \multirow[t]{2}{*}{.373} \\
\hline & & $\begin{array}{l}N . \\
\text { Disability }\end{array}$ & 121 & 42 & & \\
\hline \multirow[t]{2}{*}{8} & \multirow{2}{*}{$\begin{array}{l}\text { Students with disabilities have completed their } \\
\text { education latter in all levels of the church } \\
\text { education than students without disabilities due } \\
\text { to having low ability }\end{array}$} & Disability & 35 & 8 & \multirow[t]{2}{*}{.100} & \multirow[t]{2}{*}{.751} \\
\hline & & $\begin{array}{l}N . \\
\text { Disability }\end{array}$ & 13 & 27 & & \\
\hline \multirow[t]{2}{*}{9} & \multirow{2}{*}{$\begin{array}{l}\text { Students with disabilities have completed all } \\
\text { levels of the church education as the same time } \\
\text { as students without disabilities because of } \\
\text { having low abilities }\end{array}$} & Disability & 13 & 30 & \multirow[t]{2}{*}{1.050} & \multirow[t]{2}{*}{.305} \\
\hline & & $\begin{array}{l}N . \\
\text { Disability }\end{array}$ & 37 & 126 & & \\
\hline
\end{tabular}

Note that $H C$ refers to health condition, $A$ refers to agree, DS refers to disagree, $X^{2}$ refers to Chi-square and sig. refers to significant value, at Alpha level 0.05,df=1 
The general $\mathrm{X}^{2}$ test in the table 3 is used to compare the academic performance of students with disabilities with that of students without disabilities in the different levels of church schools. The researchers developed 9 items that used to assess differences in academic performances of students with disabilities in comparison with students without disabilities in the church schools. Accordingly, there is no statistically significant difference between the two groups of learners in their educational performance in all of the items, $X^{2}(1.509, .521, .036,1.393, .158, .015, .793, .100$, and 1.050 from item 1-9 respectively), $\mathrm{df}=1, \mathrm{p}=.220, .471, .850, .238, .691, .902, .373, .751$ and $.305>0.05$ from items $1-9$ respectively. Thus, the result indicates there is no ability difference between students with disabilities and students without disabilities in the different levels of the church schools.

\subsubsection{The Implementation of Teaching Methods}

\section{Table 2: the implementation of teaching-learning methods for students with Disabilities}

\begin{tabular}{|c|c|c|c|c|c|}
\hline \multirow[t]{2}{*}{ II } & \multirow[t]{2}{*}{ Items } & \multicolumn{2}{|c|}{ Agree } & \multicolumn{2}{|c|}{ Disagree } \\
\hline & & $f$ & $\%$ & $f$ & $\%$ \\
\hline 1 & $\begin{array}{l}\text { In church education, teachers usually practice active methods of } \\
\text { teaching }\end{array}$ & 162 & 78.65 & 44 & 21.65 \\
\hline 2 & $\begin{array}{l}\text { In church education, teachers always used only lecture method } \\
\text { of teaching. }\end{array}$ & 49 & 23.79 & 157 & 76.21 \\
\hline 3 & $\begin{array}{l}\text { In all levels of the church education, teachers used only one type } \\
\text { of method of teaching }\end{array}$ & 55 & 26.7 & 151 & 73.30 \\
\hline 4 & $\begin{array}{l}\text { The method of teaching used in the church education is } \\
\text { depends on rote memory }\end{array}$ & 86 & 41.75 & 120 & 58.25 \\
\hline 5 & $\begin{array}{l}\text { Church scholars practiced a varieties of methods of teaching for } \\
\text { students with disabilities }\end{array}$ & 88 & 42.72 & 118 & 57.28 \\
\hline 6 & $\begin{array}{l}\text { The practiced methods of teaching are appropriate for students } \\
\text { with disabilities }\end{array}$ & 156 & 75.73 & 50 & 24.27 \\
\hline 7 & $\begin{array}{l}\text { The practiced method of teaching varies from one level to } \\
\text { others levels of the church education( Nibab bet, Zema bet, Kene } \\
\text { bet and Meshaft bet) }\end{array}$ & 174 & 84.47 & 32 & 15.53 \\
\hline 8 & $\begin{array}{l}\text { The Methods of teaching employed by church scholars various } \\
\text { from disabilities to disabilities(visual from hearing) }\end{array}$ & 99 & 48.06 & 107 & 51.94 \\
\hline 9 & $\begin{array}{l}\text { Practice -centered method of teaching is not conducive for } \\
\text { students with disabilities }\end{array}$ & 159 & 77.18 & 47 & 22.82 \\
\hline
\end{tabular}

The result from Table 2 revealed that majority of the respondents, $162(78.65 \%)$ reported that church scholars have been practicing active learning methods in all levels of the church schools. On the contrary, most respondents $(76.21 \%$ ) disagreed with the issue of the implementation of lecture methods of teaching slowly. That is, teachers used other methods of teaching like independent work, active listening, 
peer tutoring, group discussion, brain storming, creative work etc. The above table also showed that teachers did not use only one type of method of teaching (73.3\%). Furthermore, a slightly large number of respondents $120(58.25 \%)$ forwarded that the methods of teaching employed on the different levels of the church education do not only depend on rote memory. It requires also understanding, creativity and practical works. Regarding the various methods of teaching used for students with disabilities, respondents 118 (57.28\%) confirms that teachers did not use different types of methods of teaching peculiarly for students with disabilities in the church education. In line with this, most respondents (75.73\%) agreed that the practiced methods of teaching were appropriate for students with disabilities. The majority of respondents (84.47\%) also forwarded that the practiced methods of teaching were varying from one level to other level of the church schools.

As the table above depicted, majority of the respondents (77.18\%) remarked that the practice centered method of teaching like aqwaqwam and using sistra, prayer sticks and drums executed by the choir are not conducive for students with visually and physically impaired. In the same vein, the data onto the table also showed that some of the respondents (48.06\%) reported that the methods of teaching employed by church scholars were vary from disabilities to disabilities. However, a considerable number of respondents was not agreed with this issue (51.94\%). They learn the curriculum by their own pace and approach. In addition, different grade leveled students attended their education to gather in one fixed learning center.

\subsubsection{Assessment Techniques}

Table 3: Assessment techniques employed in the church education 


\begin{tabular}{|c|c|c|c|c|c|}
\hline \multirow[t]{2}{*}{ III } & \multirow[t]{2}{*}{ Items } & \multicolumn{2}{|c|}{ Agree } & \multicolumn{2}{|c|}{ Disagree } \\
\hline & & $f$ & $\%$ & $f$ & $\%$ \\
\hline 1 & $\begin{array}{l}\text { Church scholars usually assess students understanding level } \\
\text { continuously }\end{array}$ & 202 & 98.06 & 4 & 1.94 \\
\hline 2 & $\begin{array}{l}\text { Church scholars assess students' understanding at the end of } \\
\text { each level/program only. }\end{array}$ & 199 & 96.68 & 7 & 3.24 \\
\hline 3 & $\begin{array}{l}\text { After the end of each assessment, church scholars provide } \\
\text { feedback immediately }\end{array}$ & 183 & 88.83 & 23 & 11.7 \\
\hline 4 & $\begin{array}{l}\text { Church scholars used special assessment techniques in order } \\
\text { to know the understanding levels of students with disabilities }\end{array}$ & 31 & 15.05 & 175 & 84.95 \\
\hline 5 & $\begin{array}{l}\text { in addition to their teachers, students ability is assessed by } \\
\text { external church scholars }\end{array}$ & 21 & 11.11 & 185 & 88.89 \\
\hline 6 & Students' with disabilities ability is assessed by their peers. & 193 & 93.7 & 13 & 6.3 \\
\hline 7 & $\begin{array}{l}\text { Students with disabilities are assessed by the same } \\
\text { assessment criteria like that of their' normal' peers }\end{array}$ & 172 & 83.49 & 34 & 16.51 \\
\hline 8 & $\begin{array}{l}\text { There is standardized fixed criteria that used to assess } \\
\text { students' abilities in all levels of the church education }\end{array}$ & 148 & 71.84 & 58 & 28.16 \\
\hline 9 & $\begin{array}{l}\text { Church scholars use similar assessment techniques for both } \\
\text { students with and without disabilities }\end{array}$ & 166 & 80.56 & 40 & 19.42 \\
\hline
\end{tabular}

As shown from the above table, most respondents (98.06\%) reported that church scholars assess their students' understanding level continuously. In the same vein, the data onto the same table revealed that majority of respondents (96.68\%) agreed that teachers also assess students' understanding level at the end of each program. This entails that church scholars assess students' performance both at each lesson continuously and at the end of each program/level. The table above also depicted that $88.83 \%$ of respondents responded that church schools have been providing feedback immediately.

However, $84.95 \%$ of the respondents answered that church scholars did not use special assessment techniques in order to know the understanding levels of students with disabilities in the different levels of church education. In addition, most respondents (88.89\%) assured that students' ability had not been assessed by external church scholars. The result from the same table also showed that the majority of the respondents (93.7\%) replied that students' ability is assessed by their peers. In the same way, $83.49 \%$ of respondents remarked that church scholars used the same type of assessment criteria for both students with and without disabilities to evaluate students' performance. Furthermore, majority of respondents $(71.84 \%)$ revealed that there is standardized fixed criteria that used to assess students' abilities in all levels of the church education. Finally, as most respondents replied, church scholars used similar assessment techniques for both students with and without disabilities (80.56\%). 


\subsubsection{Support services}

Table 4: Support services provided for students with disabilities in church education

\begin{tabular}{|c|c|c|c|c|c|}
\hline \multirow[t]{2}{*}{ IV } & \multirow[t]{2}{*}{ Items } & \multicolumn{2}{|c|}{ Agree } & \multicolumn{2}{|c|}{ Disagree } \\
\hline & & $f$ & $\%$ & $f$ & $\%$ \\
\hline 1 & $\begin{array}{l}\text { Students with disabilities have got special shelter services from } \\
\text { church schools }\end{array}$ & 70 & 66.02 & 136 & 33.98 \\
\hline 2 & $\begin{array}{l}\text { Students with disabilities have got food services from the } \\
\text { church schools }\end{array}$ & 82 & 38.91 & 124 & 60.19 \\
\hline 3 & $\begin{array}{l}\text { Students with disabilities have got academic support services } \\
\text { from the church }\end{array}$ & 108 & 52.43 & 98 & 47.57 \\
\hline 4 & $\begin{array}{l}\text { Students with disabilities have got disability specific } \\
\text { educational materials }\end{array}$ & 24 & 11.66 & 182 & 88.34 \\
\hline 5 & Students with disabilities have got clothing support services & 7 & 3.32 & 199 & 96.68 \\
\hline 6 & $\begin{array}{l}\text { Students with disabilities have got educational support services } \\
\text { from their peers }\end{array}$ & 191 & 92.72 & 15 & 7.28 \\
\hline 7 & $\begin{array}{l}\text { Students with disabilities have got special support services } \\
\text { from society }\end{array}$ & 27 & 13.1 & 179 & 86.9 \\
\hline 8 & $\begin{array}{l}\text { Students with disabilities have got special educational support } \\
\text { from church scholars }\end{array}$ & 89 & 43.2 & 117 & 56.8 \\
\hline
\end{tabular}

In light of shelter support services from church schools, 136(66.02\%) of the respondent responded disagree. Meaning, students with disabilities have not obtaining shelter support services from the church school. Furthermore, 124(60.19\%) of the respondents disagreed with the provision of food supports by the church. Instead, students have been obtaining this support from the community through begging with the help of their junior students. However, more than half $108(52.43 \%)$ of the respondents remarked that students with disabilities have got academics support from the church. The table above also showing that the majority of the respondents (88.34\%) have confirmed that students with disabilities have not been obtaining disability specific educational materials from the school.

Regarding clothing support, 199(96.68\%) and 7(3.32\%) of the participants have replied disagree and agree respectively. This entails that students with disabilities did not obtain clothing supports from the church and church schools. 191(92.72\%) of the participants also responded that students with disabilities have got educational supports from their peers. Concerning special support services from society, $179(86.9 \%)$ of the respondents replied disagree. That is, students with disabilities have not been obtaining special support services from society. In addition, slightly more than half of the respondents (56.8\%) remarked that students with disabilities could not get special educational supports from church scholars. 
3 .3 Interview, FGD and Responses from opened ended questionnaire results

Box 1: Interview, FGD and responses from open ended questionnaire 


\section{Results related to academic Ability and performance}

- Students with and without disabilities have similar educational performance ( case 9)

- Blind students have by far better performance than other groups of studentsin memory and understanding (case 4)

- The educational performance of Blind students are greater than when compared to ' normal' students( case 11)

- Students with disabilities have similar abilities and learn equally if they get support services (case 6)

- Though students with disabilities have similar abilities, they faced problems in using and playing church music with sistra, drums, prayer sticks and choirs(case 7)

- Students with disabilities do not have problems in mental abilities except in reading and learning Dawit for students with visual impairment and choir and Mass music for students with physical disabilities.)( all interviewed church scholars)

- Students with disabilities do not have problems of learning the Words of the God (FGD result)

- Some practical activities including Aqwaqquam(the way of standing and moving) and Mhelet(choiring while singing) require the participation of hand, leg and the different parts of the body. These kind of performances are so difficult for students with disabilities(Solomon)

- If we could not find readers, it is obvious that our educational performance is lower( FGD result)

- Students with disabilities have similar performance at night than days learning, because they obtained readers at night(case 2)

- There is no educational performance difference between students with and without disabilities( the open ended questionnaire result)

- No educational ability and performance difference existed on these groups of learners particularly in Qene( the composition of poetry)(case 2)

- Except having physical weakness, students with disabilities perform well in practical related performances( Dejen and FGD result)

- Church education requires bright mind. Disability by itself does not have an impact on students' academic performance Case 8 and FGD result)

- Students with visual impairment have better memory as compared to others(case 8)

\section{The implementation of teaching-learning methods}

- Mostly church scholars used oral method of teaching in all levels of church education(FGD result)

- Senior students teach junior learners (peer tutoring is the most frequently used methods of teaching (FGD result and case 1). Senior students academically support junior students who are usually known as "Kotres"

- The methods of teaching employed for the different levels of education are different. For instance, Kene learning requires creativity whereas, Zema needs oral methods of learning(Solomon)

- Reading is difficult for blind students to learn Nibab and Dawit, because no braille language teachers found in the church schools(Yared)

- Church scholars have been used the same type of methods of teaching for all groups of learners in all levels of church schools(Case 8 and case 14)

- In all levels of church education, teachers did not use special methods of teaching for students with disabilities(open ended question response)

- Church scholars used oral, independent reading and learning, critical thinking, group discussion, peer tutoring, micro teaching, creative work, group reading and loud talking, and brain storming methods of teaching. (case 11)

- Practice - centered methods of teaching is not conducive for students with visual and physical impairment(case 6)

\section{Assessment techniques}


- Asking question is the most frequently used assessment techniques in the church education(FGD response)

- In church education, learning is assessed to check whether learners know the issues, not for obtaining the certificate (FGD response)

- In addition to teachers, students with disabilities also assessed by their peers(Case 2)

- We assessed memory, oral, symbols knowledge, creative and practical skills(Eshetu)

- We give more emphasis on assessing the knowledge of students with disabilities than others(case 6)

- Students have not been getting an opportunity to evaluate their performances by external teachers. They evaluated by another schools where the final exams are taken, for instance, Church music (zema)at Bethlehem; for zemmare and mawasitat Zuramb; for mahelet and aqwaqwamin at Gondar; for qedasse at Wollo and Tigray (FGD, Case 11, Fentahun and Eshetu)

\section{Support services provided}

- No support services have been providing for students with disabilities by the church, government and non-governmental organizations( open ended questionnaire, all interviewed participants and FGD result)

- Students with disabilities have got only educational supports from their peers( Lema, Mersha and Genetu)

- We have obtained a pieces of food services from the community by begging with the support of junior 'normal' peers (interviewed students with disabilities)

- We obtained blanket and health related support from the community(Yared and FGD result)

\section{Discussion}

The result of the study showed that disability by itself does not have an impact on the educational ability of students with disabilities in the church education. Instead, church education requires bright mind and memory skills. The study also found out that the educational ability of students with disabilities is the same as that of their non-disabled peers. However, the educational performance of students with disabilities is different from disability to disability in the different level of the church education. For instance, some respondents reported that Blind students have by far better educational ability than other groups of students especially in memory and understanding. Other research findings like Adane (1991) found out that blind people were attending traditional church education, and with that they had high achievement, especially in oral learning and teaching in the Orthodox Church. The result also pinpointed that students with disabilities have better abilities on those theoretical related courses than on those programs that require practical performances. However, no educational ability and performance difference existed on these groups of learners particularly in learning Qene. Respondents also pointed out that students with different disability groups were not finished their education with the same period as that of students without disability in the different levels of the church education due to lack of support provided. In relation to this, Zelalem (2014) described, like their fellow friends, persons with disabilities were expected to pass through all levels of church education, which requires a long time. Everyone is engaged in learning and teaching. The Chi-square results from the study also showed that there is no 
ability difference between students with disabilities and students without disabilities in the different levels of the church schools.

The pedagogy of the church was highly dependent on repetition, memorization and strict adherence to the convention of the teacher. Students were not active in their learning; they simply tried to memorize word with word- the stock of knowledge which was handed down by their teacher (HaileGebriel, 1970). In contrary to this literature, the result of quantitative and qualitative data onto this research showed that church scholars have practiced active learning methods of all levels of the church schools. That is, teachers used independent work, micro teaching, creative work, critical thinking, active listening, peer tutoring, group discussion, brain storming, and loud speaking. This showed that the methods of teaching employed on the different levels of the church education do not only depend on rote memory. In relation to this finding Selamsew (2017) and Chaillot (2002) as cited in Christine (2009) explanation, senior students, though it was the churches tradition for a long time, offer academic assistance for at least one of the junior students (kotres) among new entrants up until the student completes his study in the schools( peer teaching). However, mostly church scholars used oral method of teaching in all levels of church education. Furthermore, church scholars did not use different types of methods of teaching peculiarly for students with disabilities in the church education. The result also found out that practice-centered methods of teaching like aqwaqwam and using sistra, prayer sticks and drums accompanied by the choir are not conducive for visually and physically impaired students. In relation to this finding, Selamsew (2017) identified that Akuakuam teaches the right way of body movement (which can be compared with dancing) when a church song is sung. Students with disabilities, is thus unable to walk normally due to a birth defect from both of his legs. In the same vein, some respondents reported that the methods of teaching employed by church scholars were various from disabilities to disabilities.

The result of the study also revealed that church scholars assess students understanding level continuously and at the end of each program as well. In addition, the respondents reported that church schools have been providing feedback immediately. In relation to this finding Haile Gebriel (1970) disclosed that students come to the teacher in a group of three or four, all study the same text. One of the groups reads a sentence into Amharic and then comment on it. The teacher first translates the sentence into Amharic and then comments on it. The students listen attentively and try to remember the comment word for word. However, the result showed that church scholars did not use special assessment techniques for students with disabilities in the different levels of church education. Moreover, the data also displayed that students' ability had not been assessed by external church scholars. Furthermore, church scholars used the same types of assessment methods and criteria for both students' with and without disabilities. The study also revealed that there is standardized fixed criteria that used to assess students' abilities in all levels of the church education to assess memory, oral, identifying symbols, creative and practical skills. In relation to this finding, literature found out that teachers of religious education currently use a range of formal and informal modes and techniques of assessment for feedback, evaluation and planning purpose (Curriculum online, 2010). The qualitative data also showed that questioning is the most frequently used assessment techniques in the church education to check whether learners know the issues not for obtaining the certificate. 
Respondents also responded that students with disabilities have not obtained shelter, food, clothing, and disability specific educational materials support from the church school, and special support services from society, and church scholars. In relation to this, Selamsew(2017) identified that nothing special has been done to assist a disabled student. (Schiemer, 2017) also stated that very often it was not easy to keep the enthusiasm of some teachers as they were often overburdened or lost motivation because of a lack of material, lack of special teacher education, and general lack of support, etc.

\section{Photos}

Photo 1: Students engaged in learning at Medhanialem Church School with their Blind teacher

Photo2: Blind student learn independently at church school

Photo 3: Church school at Tsegur Michael and Abune Menfeskiduse church (Debre Tabor)

\section{Conclusions}

1. There is no ability difference between students with disabilities and students without disabilities in the different levels of the church schools. The result of the study showed that disability by itself does not have an impact on the educational ability of students with disabilities in the church education. However, the educational performance of students with disabilities was different from disability to disability in the different level of the church education. Some respondents reported that Blind students have by far better educational ability than other groups of students.

2. Church scholars have practiced active learning methods of all levels of the church schools. That is, they used independent work, micro teaching, creative work, critical thinking, active listening, peer tutoring, group discussion, brain storming, and loud speaking. However, mostly church scholars used oral method of teaching in all levels of church education. Furthermore, most respondents forwarded that church scholars did not use special types of methods of teaching peculiarly for students with disabilities in the church education.

3. Most respondents remarked that church scholars assess students' understanding level both frequently and at the end of each program for the purpose of providing feedback. However, the result showed that church scholars did not use special assessment techniques for students with disabilities in the different levels of church education. Majority of the respondents also reported that students' with disabilities ability is assessed by their peers and church scholars. Questioning is the most frequently used assessment technique in the church education.

4. Most respondents replied that students with disabilities have got only the academic support services from the church and their 'normal' peers.

\section{Declaration Of Competing Interest}


None

\section{Acknowledgements}

I would like to thank Debre Tabor University for providing financial support to conduct this research project, and for invaluable assistance, advisory and encouragement. I would like also to express my gratitude to all research participants (students and church scholars) gave their time, energy and knowledge in helping me in undertaking this research. Without the contribution of these informants, the study could not have come to completion.

\section{Figures}

\section{Figure 1}

Students engaged in learning at Medhanialem Church School with their Blind teacher

\section{Figure 2}

Blind student learn independently at church school

\section{Figure 3}

Church school at Tsegur Michael and Abune Menfeskiduse church (Debre Tabor) 